\title{
Note on identity and distribution of Cynometra iripa Kostel. and $C$. ramiflora L. (Fabaceae) in the Andaman and Nicobar Islands, India
}

\author{
P. Ragavan, ${ }^{1}$ T. S. Rana, ${ }^{2}$ K. Ravichandran, ${ }^{3}$ R. S. C. Jayaraj,${ }^{4}$ K. Sivakumar, ${ }^{5}$ Alok Saxena, ${ }^{3}$ \\ P.M. Mohan ${ }^{6}$
}

1 SERB, National Post Doctoral Fellow, CSIR, National Botanical Research Institute, Rana Pratap Marg, Post Box No. 436, Lucknow 226001, India. 2 CSIR, National Botanical Research Institute, Rana Pratap Marg, Post Box No. 436, Lucknow 226001, India. 3 Department of Environment and Forest, Andaman and Nicobar Administration, Port Blair-744102, Andaman and Nicobar Islands, India. 4 Rain Forest Research Institute, Jorhat-785010, Assam, India. 5 Centre for Advances studies in Marine Biology, Annamalai University, Parengipettai, Tamil Nadu, India. 6 Department of Ocean Studies and Marine Biology, Pondicherry University, Brookshabad Campus, Port Blair-744112, Andaman and Nicobar Islands, India.

Corresponding author: P. Ragavan, pandivan.ragavan@gmail.com

\begin{abstract}
The present study revealed the identity and distribution of Cynometra iripa and C. ramiflora in the Andaman and Nicobar Islands, India. Of these, C. iripa is often classified as true mangrove species, whereas C. ramiflora is a mangrove associate. Apex of leaflets, length of inflorescences, length of pedicels, apex of anthers and position of fruit beak are distinguishing key characters between $C$. iripa and C. ramiflora. Photographs, a key to the species, and notes on nomenclatural ambiguity are provided.
\end{abstract}

\section{Key words}

Cynometra spp; Andaman and Nicobar Islands; mangroves; distribution.

Citation: Ragavan P, Rana TS, Ravichandran K, Jayaraj RSC, Sivakumar K, Saxena A, Mohan PM (2017) Note on identity and distribution of Cynometra iripa Kostel. and C. ramiflora L. (Fabaceae) in the Andaman and Nicobar Islands, India. Check List 13 (6): 805-812. https://doi. org/10.15560/13.6.805

\section{Introduction}

The genus Cynometra L. (Fabaceae) consists of about 85 species distributed in the tropical regions (Mabberley 2008). The genus is characterised by unijugate or bijugate leaves, small bud scales, 4 calyx lobes, 5 petals, 10 stamens, and 1-seeded fruits. In India, Cynometra is represented by 7 species: C. beddomei Prain, C. bourdillonii Gamble, C. iripa Kostel., C. malaccensis Meeuwen, C. ramiflora L., C. travancorica Bedd., and C. cauliflora L. (Sanjappa 1992). Of these, taxonomical identity and distribution of $C$. ramiflora and $C$. iripa have often been problematic as $C$. iripa was considered as a variety of $C$. ramiflora in the past (Meeuwen 1970). Cymorium sylvestre of Rumphius (1741: pl. 63) was described as Cynometra ramiflora by Linnaeus (1753), which is characterized by unijugate leaves. Iripa of Rheede (1682: pl. 31) was described as Cynometra iripa by Kosteletzky (1835), which is characterized by bijugate leaves. However, most of the subsequent botanists described Cynometra iripa as varietal form of C. ramiflora. For instance, Prain (1897) described 2 subspecies of $C$. ramiflora, subsp. genuina (unijugate form) and subsp. bijuga (bijugate form), based on number of leaflets. Furthermore, he recognized 
2 varieties of subsp. bijuga based on leaflet size and tip shape: var. mimosoides (smaller leaflets with obtuse tip) and var. heterophylla (larger leaflets with acute to acuminate leaflets). Thus, it is noteworthy that Prain described the bijugate form of C. ramiflora as var. heterophylla and unijugate as subsp. genuina, whereas var. mimosoides was used to describe C. iripa. Subsequently, Prain (1903) separated var. mimosoides from $C$. ramiflora and treated it as a distinct species. From this, it is apparent that $C$. iripa was placed as distinct species by Prain (1903) and var. heterophylla and subsp. genuina (i.e., the unijugate and bijugate forms of $C$. ramiflora respectively) were placed under $C$. ramiflora $\mathrm{L}$. In the taxonomical revision of the genus Cynometra, Meeuwen (1970) also treated "subsp. genuina" and "subsp. heterophylla" as synonyms of $C$. ramiflora and "var. mimosoides" and "subsp. bijuga" are treated as synonyms of $C$. iripa. Further, he also noted that "for no obvious reason, $C$. iripa was considered in the past as a variety of $C$. ramiflora and it is entirely different from $C$. ramiflora; the only character they share is a deeply rugose pod, but even the shape of the pod is different". Ding Hou et al. (1996) also described the Cynometra species in Flora Malesiana based on the taxonomical revision of Meeuwen (1970).

Both C. iripa and C. ramiflora were known from Andaman and Nicobar Islands (A \& N Islands). However, the identity and distribution of C. iripa and C. ramiflora are far from complete. For instance, in Forest flora of Andamans, Parkinson (1923) reported 2 varieties of Cynometra ramiflora - var. heterophylla and var. mimosoides. He further emphasized that terminal leaflets are much larger than the lower and acute in var. heterophylla, whereas in var. mimosoides terminal leaflets are hardly larger than the lower and obtuse. He also pointed out that the former one was very rare and latter was most common behind the mangrove swamps in the Andaman Islands. Those notes clearly indicated that his var. heterophylla was C. ramiflora and var. mimosoides was C. iripa. Subsequent to Parkinson (1923), C. ramiflora and C. iripa are reported by Dagar (1987), Dagar et al. (1991), Dagar and Singh (1999), and Debnath (2004). Among them, Dagar (1987) and Dagar et al. (1991) classified both the species as true mangroves and noted that $C$. ramiflora is common in the $\mathrm{A} \& \mathrm{~N}$ Islands and $C$. iripa is rare, whereas Debnath (2004) classified these species as mangrove associates and noted that C. ramiflora is very rare and $C$. iripa is common everywhere behind the mangrove swamps. Dagar and Singh (1999) reported $C$. iripa and 3 varieties of C. ramiflora-var. heterophylla, var. bijuga, and var. mimosoides — but the descriptions are not clear. Further, none of them have given locality data for C. ramiflora in the A \& N Islands.

In the bibliographic and distributional account on legumes of India Sanjappa (1992) reported both the species and noted that $C$. iripa is found in Odisha, West Bengal and A \& N Islands, whereas C. ramiflora is found only in the A \& $\mathrm{N}$ Islands. In contrast, Lakshminarasimhan (1999) reported only C. iripa from the A \& N Islands and noted that $C$. ramiflora is not found in India including A \& N Islands. Kathiresan (2008) reported the occurrence of both $C$. ramiflora and $C$. iripa from the Sundarbans, Odisha and A \& N Islands and only C. iripa from Maharashtra. Mandal and Naskar (2008) reported the occurrence of only C. ramiflora in all the mangrove habitats of India, except Lakshadweep, without description and locality data. Hence, keeping all the previous studies in view, present study was undertaken with the objective to resolve the nomenclatural ambiguity of $C$. iripa and C. ramiflora in the A \& N Islands and to document their distribution.

\section{Methods}

Recent floristic study on species diversity and distribution of mangroves of the A \& N Islands revealed the occurrences of 2 species of Cynometra, C. iripa and $C$. ramiflora. Specimens were collected to assess the numeric and multistate attributes of a wide range of vegetative and reproductive morphological characters and were identified using regional floras (Baker 1878, Brandis 1906, Prain 1903, Parkinson 1923), monographs (Meeuwen 1970, Prain 1897), and standard references (Tomlinson 1986, Giesen et al. 2006). Collected specimens were also compared with specimens deposited at the Andaman and Nicobar Regional Centre, Botanical Survey of India, Port Blair (PBL) and electronic resources such as the Angiosperm Phylogeny Website (Stevens 2001), Tropicos of Missouri Botanical Garden, REMIB (World Biodiversity Information Network), Kew Herbarium Database, Global Plants Initiative, ePIC (electronic Plant Information Centre 2002), and IPNI (The International Plant Names Index 2012). Voucher specimens of C. iripa (Accession No. 30939, 30940) and C. ramiflora (Accession No. 30941, 30942) have been deposited at PBL.

\section{Results}

Of the 51 sites surveyed, C. iripa was recorded at 29 sites in the Andaman Islands, whereas few individuals of $C$. ramiflora were recorded from Chidiyatapu, South Andaman (Fig. 1). None of them was recorded from the Nicobar Islands. Taxonomical description and photoplates of C. iripa and C. ramiflora of A \& N Islands has also been provided to facilitate identification. The distinguishing key characters of both the species are given in Table 1 .

\section{Key to existing species of Cynometra species in the A \& N Islands}

1a Leaves 2-jugate, upper leaflets not much unequal; rachis of inflorescences $0.2-0.35 \mathrm{~cm}$ long; flowers with bent style; fruits rugose with prominent lateral

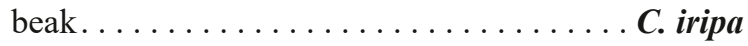

1b Leaves 1- or 2-jugate, upper leaflets much larger than lower; rachis of inflorescences 1-2 cm long, flowers with straight style; fruits rugose with sub-terminal beak. . . . . . . . . . . . ramiflora 


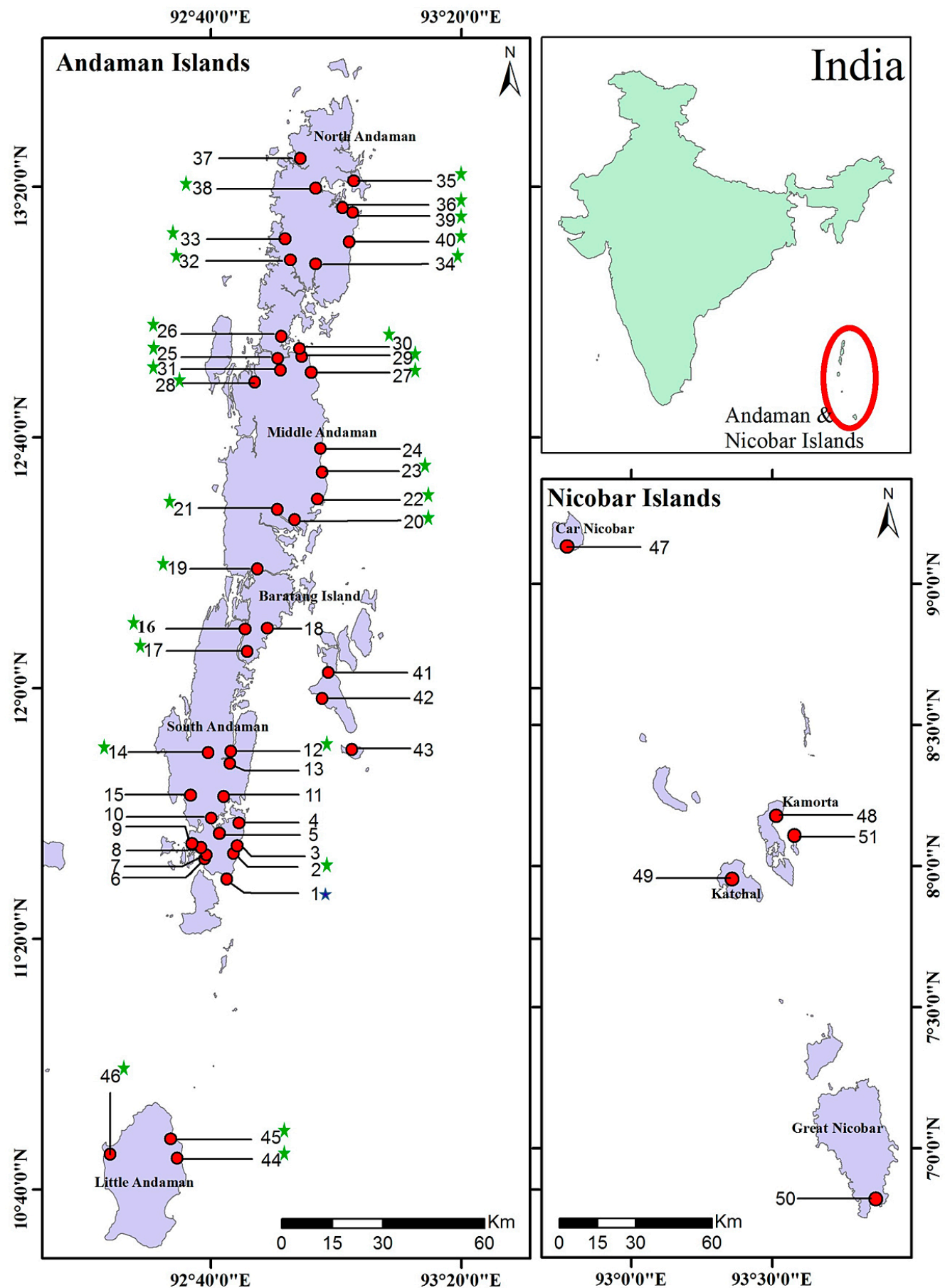

Figure 1. Map showing study area. Red spots indicate sites surveyed in A \& N Islands, green star indicates localities of Cynometra iripa, and blue star indicates locality of C. ramiflora. South Andaman: 1. South bay; 2. Chidiyatapu; 3. Burmanallah; 4. Beadonabad; 5. Corbyn's Cove; 6. Sippighat; 7. Manjeri; 8. Guptapara; 9. Manglutan; 10. Wandoor; 11. Ograbraj; 12. Bambooflat Creek; 13. Wright Myo creek; 14. Shoal Bay Creek; 15. Jirkatang-Tirur; 16. Middle Strait; 17. Wrafter's Creek; 18. Baludera. Middle Andaman: 19. Kadamtala Creek; 20. Yerrata Creek; 21. Shyamkund Creek; 22. Dhaninallah Creek; 23. Rangat Bay; 24. Panchawati; 25. Austin Creek; 26. Mohanpur Creek; 27. Karmatang Creek; 28. Chainpur Creek; 29. Rampur; 30. Danapur; 31. Tugapur. North Andaman (Diglipur): 32. Parangara Creek; 33. Kishorinagar Creek; 34. Kalighat Creek; 35. Smith Island; 36. Ariel bay; 37. Radhanagar; 38. Lakshmipur; 39. Durgapur; 40. Ramnagar. Havelock Island: 41. Govindnagar; 42. Radhanagar; 43. Neil Island. Little Andaman: 44. V.K. Pur Creek; 45. Dugong Creek; 46. Jackson Creek. Nicobar Islands: 47. Car Nicobar; 48. Kamorta; 49. Katchal; 50. Campbell Bay; 51. Trinket Island.

Cynometra iripa Kostel. Allg. Med.-Pharm. Fl. 4: 1341. 1835 .

Figures 2-11

C. ramiflora var. mimosoides Baker in Hooker's Fl. Brit. India. 2: 267 1878; Parkinson, For. Fl. Andaman Islands.123.1923. C. ramiflora ssp. bijuga Prain var. mimosoides Prain, J. Asiat. Soc. Bengal 66 (1): 198 478; 66 (2): 478. 1897. C. mimosoides Prain, Ree. Bot. Surv. India 2: 303.
1903; Brandis, Ind. Trees 708. 1906; Gamble, Fl. Pres. Madras 3: 414. 1919. C. bijuga var. mimosoides Merr., Philip. J. Sc. (Bot) 5: 36. 1910.

Tree: evergreen, spreading, 3-10 m high. Bark: smooth, brown-grey, patchy, finely fissured. Leaves: 2jugate, alternate; leaflets green, coriaceous, glabrous, margin entire, mid vein off centered, elliptic, apex obtuse with notched 

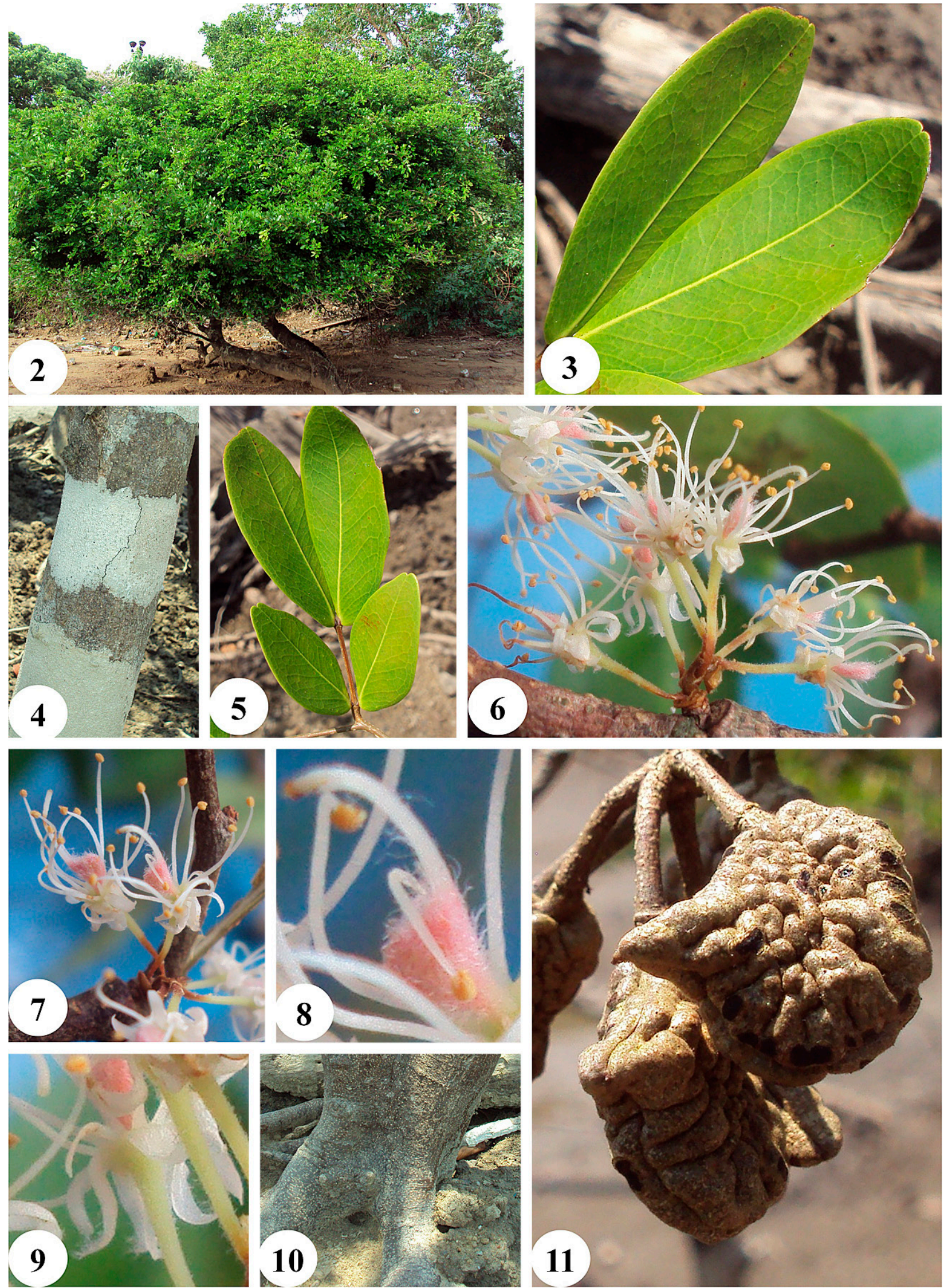

Figures 2-11. Morphological features of Cynometra iripa. 2. Habit. 3. Leaflets with blunt emarginate tip. 4. Bark. 5. Leaf with 2 pairs of leaflets. 6. Inflorescence. 7. Flowers. 8. Hairy ovary and bent style. 9. Reflexed calyx lobes. 10. Stem base. 11. Wrinkled pod with lateral beak. 
Table 1. Comparison of diagnostic characters of Cynometra iripa and C. ramiflora.

\begin{tabular}{lll}
\hline Characters & C. iripa & C. ramiflora \\
\hline Leaflet size & Lower pair smaller than upper, not much varied & Upper pair much larger than lower \\
Apex of the leaflets & Obtuse to round & Acute to acuminate \\
Length of rachis of inflorescence & $0.2-0.35 \mathrm{~cm}$ & $1-2 \mathrm{~cm}$ \\
Length of the pedicels & $0.3-0.5 \mathrm{~cm}$ & $0.7-1.3 \mathrm{~cm}$ \\
Style & Bent, glabrous, not in line with the dorsal side of the & Straight, in line with the dorsal part of the ovary, a few \\
& ovary & hairs up to halfway \\
Ovary & Densely hairy & Slightly hairy \\
Mature fruits & Rugose with prominent lateral beak & Rugose with sub-terminal beak, beak not prominent as \\
& & in C. iripa \\
\hline
\end{tabular}

tip, base cuneate, $2-6.5 \times 1-3 \mathrm{~cm}$, lower pair often smaller; petioles $0.1-0.4 \mathrm{~mm}$ long, minutely pubescent; petiolules c. $0.2 \mathrm{~cm}$ long. Inflorescence: axillary, capitate, 3-7 flowered; bracteoles 1 or 2 towards pedicel base, filiform, $0.15-0.3 \mathrm{~cm}$ long, sparsely hairy, caduceus, rachis $0.2-0.35 \mathrm{~cm}$ long. Mature flower buds: globular, covered by bract; pedicels $0.3-0.5 \mathrm{~cm}$ long, hairy. Calyx: 4-lobed, c. $0.5 \mathrm{~cm}$ long, lanceolate or oblong-ovate, becoming reflexed and often incurved at apex, white or very pale pink reflexed. Corolla: 5, creamy white, lanceolate, $0.5-0.8 \mathrm{~cm}$ long, glabrous, caduceus, reflexed. Stamens: 10, filaments slender, $0.5-0.7 \mathrm{~cm}$ long; anthers small with apiculate apex. Ovary: hairy outside and inside, inserted eccentrically on a short stalk; style slender, glabrous, bent not in line with the dorsal side of the ovary, c. 0.5 $\mathrm{cm}$ long, stigma capitate. Mature fruit: 1-seeded, woody, wrinkled with distinct lateral beak, green turning brown on maturity, 2-3.5 × 1.5-2.5 cm.

Phenology. Flowering August to December; fruiting January to April.

Habitat. Often occurs in landward margin of mangrove in association with Aegiceras corniculatum (L.) Blanco, Phoenix paludosa Roxb., and Heritiera littoralis Aiton.

Distribution. Reported only from Andaman Islands in Andaman Nicobar Islands.

Specimens examined. India, Andaman and Nicobar Islands: South Andaman, Chediyatapu, 29-May-1974, Thothathri \& N.G. Nair 1086; South Andaman, Chidiyatapu, 28-Feb-1975, N. Bhargava \& N.G. Nair 2263; Smith Island, 25-Nov-1976, N.G. Nair 4912; South Andaman, Chidiyatapu, 05-Dec-1978, P. Basu 7081; South Andaman, Chidiyatapu, 16-Mar-1980 Rao \& Chakraborthy 7647; Mayabunder, Parangada, 20-Jan-1988, G.S. Lakra \& M. Tigga 16985; Baratang, 29-Jan-1994, Maral Tigga 16632; Diglipur, 25-Sep-1996, G.S. Lakra 15084; Rutland, 12-Apr-2002, K. Karthigeyan 19209; Tarmugli, 30-Nov2002, K. Karthigeyan 19242; Great Nicobar Island, Dongi Nallah, 19-Jan-2004, J. Jayanthi 19991; South Anda-

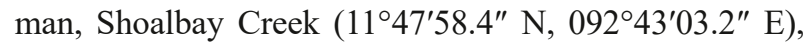
24-Mar-2014, P. Ragavan 30939, 30940 (PBL).

Conservation Status. Categorized as Near Threatened by the IUCN and its population declining throughout its range due to coastal development (Duke et al. 2010).
Cynometra ramiflora L. Sp. P1. 1: 382-383. 1753.

Figures 13-22

C. ramiflora L., Baker in Hook, f., Fl. Brit. India 2: 267. 1878; Brandis, Ind. Trees 255. 1906. C. ramiflora ssp. genuina Prain, J. Asiat. Soc. Bengal 66(2): 198. 1897. C. bijuga Span. ex Miq., Fl. Ind. Bat. 1(1): 78. 1855; Kurz, J. Asiat. Soc. Beng. 45(2): 129 \& 289. 1876. C. ramiflora ssp. bijuga Prain, J. Asiat. Soc. Bengal 66(1): 198 \& 66(2): 478. 1897. C. ramiflora var. heterophylla Thwaites, Enum. Ceyl. Pl. 97. 1859; Baker in Hook, f., Fl. Brit. India 2: 267. 1878; Parkinson, For. Fl. Andaman Islands 325. 1923. C. ramiflora ssp. bijuga var. heterophylla Prain, J. Asiat. Soc. Bengal 66(2): 198 \& 66(2): 478.1897.

Tree: evergreen, spreading, 3-10 m high. Bark: smooth, brown-grey, patchy with numerous lenticels. Leaves: 1 or 2jugate, alternate; leaflets green, coriaceous, glabrous, margin entire, mid vein off centered, elliptic, apex acute with notched leaf tip, base cuneate or attenuate, 3.5-15 $\times 2-5.5 \mathrm{~cm}$, lower pair often smaller, terminal leaflets much larger; petiole $0.5-1.5 \mathrm{~cm}$ long, minutely pubescent; petiolules c. $0.2 \mathrm{~cm}$ long. Inflorescence: axillary, capitate, 3-10 flowered; bracteoles near pedicel bases boat-shaped and keeled, $0.2-0.3 \times$ c. $0.15 \mathrm{~mm}$, ciliate at apex, caduceus; rachis 1-2 cm long; Mature flower buds: globular, covered by bract; pedicels $0.7-1.3 \mathrm{~cm}$ long, glabrous. Calyx: 4-lobed, white, c. $0.5 \mathrm{~cm}$ long, apex acute, margin entire, glabrous, reflexed. Corolla: 5, creamy white, lanceolate, $0.6-1 \mathrm{~cm}$ long, caducous, glabrous, apex acute or mucronate, margin entire, not reflexed as in C. iripa. Stamens: 10; filaments slender, 0.7-1 cm long; anthers small with slightly apiculate apex. Ovary: curly hairy outside, glabrous inside, inserted eccentrically on a short stalk; style slender, straight, hairy at base, 0.5-0.8 cm long; stigma capitate. Mature fruits: 1-seeded, woody, wrinkled with sub-terminal beak, green turning brown on maturity, $2-2.5 \times 1-1.5 \mathrm{~cm}$.

Phenology. Flowering December to January; fruiting January to February.

Habitat. Found on landward margins of mangroves on the banks of the freshwater stream in association with Bruguiera cylindrica (L.) Blume, and Heritiera littoralis Aiton.

Distribution. Rare, found only in Chidiyatapu, South Andaman Island in the present study. However, it has also been known in the past from Nicobar Islands.

Specimens examined: India, Andaman and Nicobar 

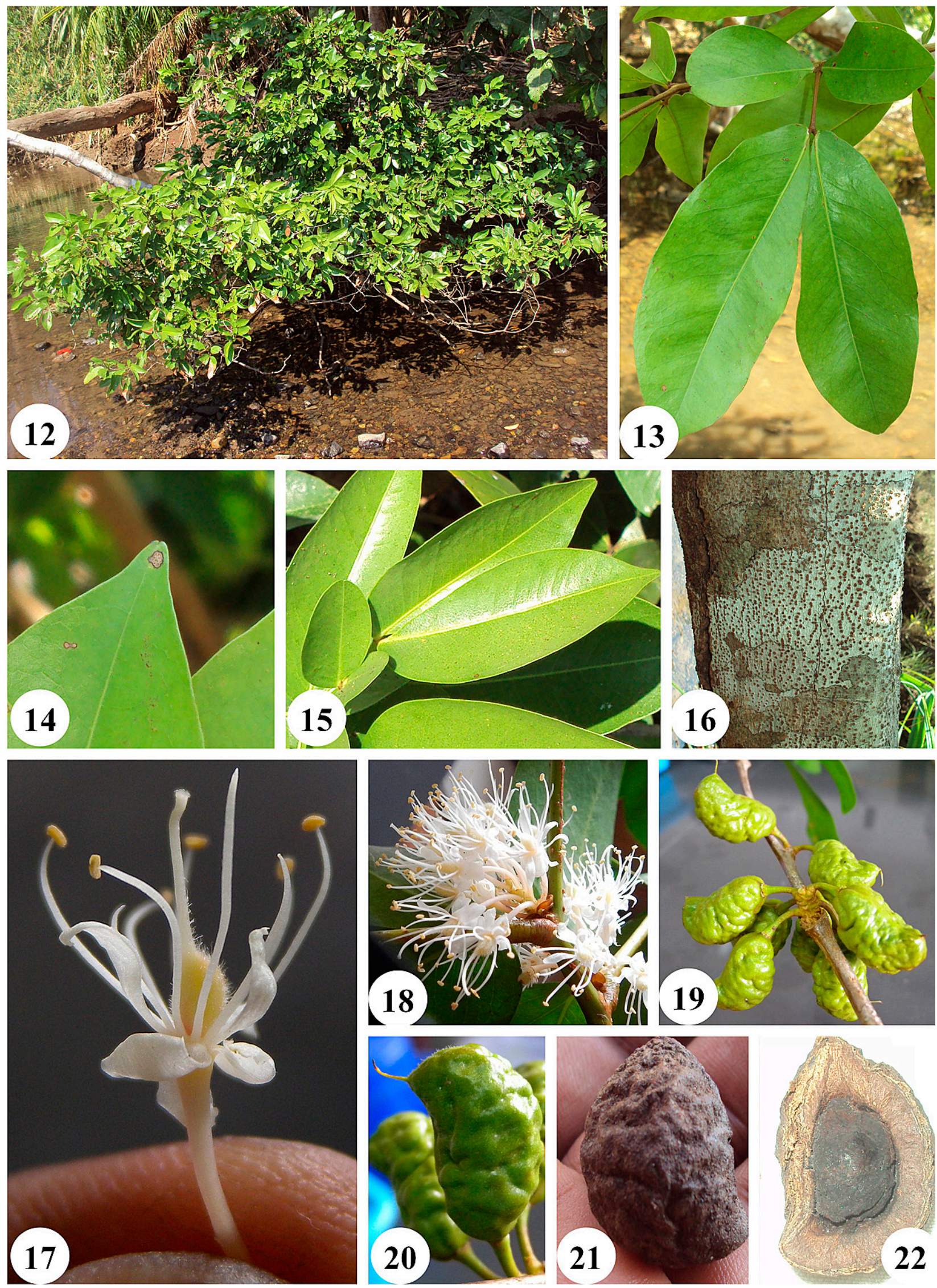

Figures 12-22. Morphological features of Cynometra ramiflora. 12. Habit. 13. Leaf with two pairs of leaflets. 14, 15. Leaflets with pointed emarginate tip. 16. Bark. 17. Flower. 18. Inflorescence. 19. Fruit cluster. 20. Fruit with sub-terminal beak. 21. Mature fruit. 22. Seed. 
Islands: Katchal Island, Aat Kona nallah, 30.03.1979, Vasudeva Rao 7502, 7503; Car Nicobar, Near freshwater streams, 01-Oct-1979, N.G. Nair 7498, 7499; Car Nicobar, 15-Jun-1974, N.G. Nair 7496, 7497; Katchal Island, 14-Jun-1977, Chakraborthy 6037; Great Nicobar, 27Oct-1979, D.K. Hore 7722; South Andaman Island, Chidiyatpu $\left(11^{\circ} 29^{\prime} 31.2^{\prime \prime} \mathrm{N}, 092^{\circ} 42^{\prime} 33.6^{\prime \prime}\right.$ E), 15-Jun2014, P. Ragavan 30941, 30942 (PBL).

\section{Discussion}

The synonyms of $C$. ramiflora based on the differences in the number and size of leaflets (characters of minor importance) often causing confusion with C. iripa (Meeuwen 1970). Cynometra iripa is distinguished from C. ramiflora by its eccentric bent style, hairy ovary, distally curved calyx lobes, and fruit with prominent lateral beak, whereas in C. ramiflora style is straight, ovary curly hairy outside and glabrous inside, calyx lobes erect, and fruits with sub-terminal beak (Meeuwen 1970, Ding Hou et al. 1996, Giesen et al. 2006). Considering the distribution of C. iripa and C. ramiflora, Prain (1897) noted that $C$. ramiflora subsp. genuina (unijugate form of $C$. ramiflora) has never been collected in Indian territory, var. mimosoides was noted in Sundarbans, Malabar, Ceylon, Burma, Andamans (very common); distribution of var. heterophylla was noted in Ceylon, Andamans; Coco Group, and South Andaman (very rare), Malay Peninsula and Singapore. From these notes, it is clear that $C$. iripa (= var. mimosoides) was observed from mainland India and Andaman Islands, whereas C. ramiflora (= var. heterophylla) was observed only in Andaman Islands and it is very rare.

In the present study $C$. iripa was observed exclusively in mangrove swamps, whereas $C$. ramiflora was observed on banks of the freshwater in back mangrove towards inland side. Cynometra iripa was found common in the Andaman Islands, whereas only a few individuals of C. ramiflora were recorded from Chidiyatapu, South Andaman. Earlier, Prain (1897) and Parkinson (1923) also noted rare distribution of C. ramiflora in the South Andaman Islands. However, Sinha (1999) reported the occurrence of $C$. ramiflora from fringes of Galathea Bay and specimens of C. ramiflora and C. iripa from Nicobar Islands are also available in BSI, Regional Centre at Port Blair. Of these, specimen deposited by N.G Nair (Accession no. 7498, 7499, 7496, 7497) from Car Nicobar, Chakraborty (Accession no.6037) and Vasudeva Rao (Accession no.7502, 7503) from Katchal Island and D.K. Hore (Accession no.7722) from Great Nicobar Island are verified here as $C$. ramiflora. J. Jayanthi deposited specimens of C. iripa (Accession No. 19991) from Great Nicobar Island in 2004. It has been reported that the geomorphologic changes caused by the 2004 catastrophic event drastically affected the mangroves and other coastal vegetations of Nicobar Islands (Sridhar et al. 2006). Recent floristic study carried out by Nehru and Balasubramanian (2014) also noted the drastic change in the floral composition in Nicobar Islands. It is suspected, therefore, that permanent submergence might have led to the extinction of these species from the Nicobar Islands, although this needs to be validated by more extensive and thorough surveys for Cynometra species in the Nicobar Islands. Furthermore, limited site-specific survey confined to mangroves of Nicobar Islands could also be the possible reason for its absence in the present study.

Both C. iripa and C. ramiflora are often classified as true mangrove species in India (Naskar 2004, Kathiresan 2008, MoEF 2008, Sanjappa et al. 2011), but only C. iripa is the most common representative in mangrove swamps (Meeuwen 1970) and classified often as a true mangrove species globally (Duke 1992, Polidoro et al. 2010), whereas C. ramiflora is found commonly in the fringes of the freshwater streams or back mangroves and also found inland. Nevertheless, C. iripa does not have any adaptive features (like pneumatophores, stilt root, and vivipary) to consider it as a true mangrove species, thus C. iripa is not categorized as "core" mangrove species (Spalding et al. 2010). In other parts of India, $C$. iripa was recorded from Sundarbans, Odisha and Maharashtra (Sanjappa 1992, Bhosale 2002) and C. ramiflora was found only in the A \& N Islands. Both C. iripa and C. ramiflora are threatened in India as different parts of these species have considerable medical significance (Bandaranayake 1998). The information provided in this communication will be helpful to take effective conservation measures for the protection and propagation of $C$. iripa and C. ramiflora.

\section{Acknowledgements}

The authors are thankful to Science and Engineering Research Board, DST, New Delhi for funding under National Post Doctoral Fellowship scheme. We are extremely grateful to the Department of Environment and Forests, Andaman, and Nicobar Administration for providing necessary support in conducting the survey.

\section{Authors' Contributions}

PR, KR, and PMM collected specimens; PR and TSR identified the specimen; and PR, AS, RSC, and KS wrote the paper.

\section{References}

Baker JG (1878) Leguminosae. In: Hooker JD (Ed) The Flora of British India. Vol 2: 267-268.

Bandaranayake WM (1998) Traditional and medicinal uses of mangroves. Mangroves Salt Marshes 2: 133-148.

Bhosale LJ (2002) New mangrove records for the coast of Maharashtra: a note. Seshaiyana 10: 1 .

Brandis D (1907) Indian Trees. Constable, London, 767 pp.

Dagar JC (1987) Mangrove vegetation, its structure, ecology, management and importance with special reference to Andaman and Nicobar Islands. In: Proceedings of the Symposium on Management of Coastal Ecosystems and Oceanic Resources of the Andamans, 17-18 July 1987, Andaman Science Association, Central Agricul- 
tural Research Institute, Port Blair, 8-23.

Dagar JC, Mongia AD, Bandyopadhyay AK (1991) Mangroves of Andaman and Nicobar Islands. Oxford and IBH Publishing, New Delhi, $166 \mathrm{pp}$.

Dagar JC, Singh NT (1999) Plant resources of the Andaman and Nicobar Islands Vol. I. Bishen Singh and Mahendra Pal Singh, Dehra Dun, $271 \mathrm{pp}$.

Debnath HS (2004) Mangroves of Andaman and Nicobar Islands: taxonomy and ecology. Bishen Singh and Mahendra Pal Singh, Dehra Dun, 133 pp.

Ding Hou, Larsen S, Larsen K (1996) Flora Malesiana. Ser. I, Vol 12(2). Rijksherbrium/Hortus Botanicus, Leiden University, Leiden, 409-730.

Duke NC (1992) Mangrove floristics and biogeography. In: Robertson AI, Alongi DM (Eds) Tropical Mangrove Ecosystems. American Geophysical Union, Washington, DC, 63-100.

Duke N, Kathiresan K, Sukardjo S (2010) Cynometra iripa. The IUCN Red List of Threatened Species 2010: e.T178829A7619971. https:// doi.org/10.2305/iucn.uk.2010-2.rlts.t178829a7619971.en. Accessed on: 2017-10-15.

Giesen W, Wulffraat S, Zierenand M, Scholten L (2006) Mangrove Guidebook for Southeast Asia. FAO and Wetlands International, RAP publication, Bangkok, 769 pp.

IPNI (2015) The International Plant Names Index. http://www.ipni.org Accessed on: 2015-08-10.

Kathiresan K (2008) Biodiversity of mangrove ecosystems. Proceedings of Mangrove Workshop, GEER Foundation, Gujarat, India, $17 \mathrm{pp}$.

Kosteletzky VF (1835) Allgemeine Medizinisch-Pharmazeutische Flora, vol. 4. von Heinrich Hoff, Mannheim, 476 pp.

Lakshminarasimhan P (1999) Caesalpiniaceae. In: Hajra PK, Rao PSN, Mudgal V (Eds) Flora of Andaman and Nicobar Islands. Vol. 2. Calcutta: Botanical Survey of India, Calcutta, 486pp.

Linnaeus C (1753) Species plantarum. Impensis Laurentii Salvii, Stockholm, $382 \mathrm{pp}$.

Mabberley DJ (2008) Mabberley's Plant-Book, 3rd edition. Cambridge University Press, United Kingdom, $1021 \mathrm{pp}$

Mandal RN, Naskar KR (2008) Diversity and classification of Indian mangroves: a review. Tropical Ecology 49: 131-146.

Meeuwen MSK (1970) A revision of four genera of the tribe Leguminosae-Caesalpinioideae-Cynometreae in Indomalesia and the Pacific. Blumea 18: 1-52.

Missouri Botanical Garden (2015) Tropicos.org. http://www.tropicos org. Accessed on: 10-08-2015.

MoEF (2008) Mangroves for the Future: National Strategy and Action
Plan, India (Revised Draft). Ministry of Environment and Forests, Government of India, New Delhi, 63 pp.

Naskar KR (2004) Manual of Indian Mangroves. Daya Publishing House, New Delhi, India, 220 pp.

Nehru P, Balasubramanian P (2014) Recovery rate of vegetation in the tsunami impacted littoral forest of Nicobar Islands, India. Forest Ecology and Management 313: 243-253. https://doi.org/10.1016/j. foreco.2013.11.023

Parkinson CE (1923) A Forest Flora of the Andaman Islands. Indian Government Central Press, Shimla, 325 pp.

Polidoro BA et al. (2010) The loss of species: mangrove extinction risk and geographic areas of global concern. PLoS ONE 5: e10095. https://doi.org/10.1371/journal.pone.0010095

Prain D (1897) Some additional Leguminosae. Journal of the Asiatic Society of Bengal 66 (2): 478-479.

Prain D (1903) Flora of the Sundribuns. Records of the Botanical Survey of India. 2(4): 1-303.

Rheede tot Draakestein H.A. van (1682) Hortus Indicus Malabaricus, vol. 4. Joannis van Someren \& Joannis van Dyck, Amsterdam, 65-66.

Royal Botanic Gardens, Kew (2002) Electronic Plant Information Centre. http://epic.kew.org/epic/. Accessed on: 2015-08-10.

Rumphius GD (1741) Herbarium Amboinense, vol. 1. Apud Fransicum Changuion, Joannem Catuffe, Hermanum Uytwerf, Amsterdam, 166-167.

Sanjappa M (1992) Legumes of India. Bishen Singh Mahendra Pal Singh, Dehra Dun, 338 pp.

Sanjappa M, Venu P, Arisdasan W, Dinesh-Albertson W (2011) A Review of mangrove species in India. In: Bhatt JR, Macintosh DJ, Nayar TS, Pandey CN, Nilaratna BP (Eds) Towards Conservation and Management of Mangrove Ecosystems in India. IUCN India, New Delhi, 35-50.

Sinha BK (1999) Flora of Great Nicobar Island. Botanical Survey of India, Calcutta, $219 \mathrm{pp}$.

Spalding M, Kainuma M, Collins L (2010) World Atlas of Mangroves. Earthscan, London. 336 pp.

Sridhar R, Thangaradjou T, Kannan L, Ramachandran A, Jayakumar S (2006) Rapid assessment on the impact of tsunami on mangrove vegetation of the Great Nicobar Island. Journal of Indian Society of Remote Sensing 34: 89-93.

Stevens PF (2001) Angiosperm phylogeny website. University of Missouri and Missouri Botanical Garden. Version 12. http://www. mobot.org/MOBOT/research/APweb/. Accessed on: 2015-08-10.

Tomlinson PB (1986) The Botany of Mangroves. Cambridge University Press, New York, 419 pp. 